\title{
The plasminogen activator inhibitor system in colon cancer cell lines is influenced by the $\mathrm{CO}_{2}$ pneumoperitoneum
}

\author{
Petra Krause • Nina S. Bobisch • Paul Thelen • \\ Karola Koehler • Sarah Koenig • Heinz Becker • \\ Ingo Leister
}

Accepted: 17 September 2010 /Published online: 8 October 2010

(C) The Author(s) 2010. This article is published with open access at Springerlink.com

\begin{abstract}
Purpose Laparoscopic surgery in the treatment of colon carcinoma causes $\mathrm{pH}$ value alterations as well as changes in fibrinolytic activity. This results in enhanced proliferation of colon carcinoma cells in vitro and also in enhanced growth of liver metastasis when compared to isobaric (gasless) laparoscopy in vivo. So far, the direct influence of $\mathrm{CO}_{2}$ pneumoperitoneum on the invasiveness and metastatic capabilities of colon cancer cells remains unclear. We therefore evaluated transcripts of the uPA system.

Methods The influence of $\mathrm{CO}_{2}$ pneumoperitoneum on the gene expression of plasminogen activator inhibitor-1 (PAI1), urokinase-type plasminogen activator (uPA), and tissuetype plasminogen activator (tPA) was investigated in colon carcinoma cell lines (HT116, SW48, and WiDr) and
\end{abstract}

P. Krause $\cdot$ N. S. Bobisch $\cdot$ S. Koenig $\cdot$ H. Becker

Department of General and Visceral Surgery,

University Medical Centre Goettingen,

Robert-Koch-Str. 40,

37075 Goettingen, Germany

P. Thelen

Department of Urology, University Medical Centre Goettingen,

Robert-Koch-Str. 40,

37075 Goettingen, Germany

K. Koehler

Department of Genetic Epidemiology,

University Medical Centre Goettingen,

Humboldtallee 32,

37073 Goettingen, Germany

I. Leister $(\bowtie)$

Centre of Minimal Invasive, Endocrine, and Visceral Surgery,

Hospital Waldfriede,

Argentinische Allee 40,

14163 Berlin, Germany

e-mail: i.leister@waldfriede.de mesothelial cells employing a pneumoperitoneum chamber in vitro. Quantitative gene expression data were collected using real-time RT-PCR and statistical analysis was performed by means of analysis of variance and Bonferroni correction. Results The expression of UPA and PAI-1 was increased in colon carcinoma cell lines when cultivated at $\mathrm{pH}$ 6.1, a value corresponding to intraabdominal $\mathrm{pH}$ values during $\mathrm{CO}_{2}$ insufflation. Elevated PAI-1 mRNA levels were also observed when $\mathrm{CO}_{2}$ was simultaneously applied with a pressure of $10 \mathrm{mmHg}$. In contrast, there were no significant changes in mesothelial cells in the investigated parameter. Conclusion The conditions of $\mathrm{CO}_{2}$ pneumoperitoneum cause changes in the expression of genes controlling the fibrinolytic activity. The increase of PAI-1 and uPA can contribute to the enhancement of metastasis and invasive potential of tumour cells. Therefore, changes in the conditions of laparoscopy may well optimise laparoscopic therapy in colon cancer.

Keywords $\mathrm{CO}_{2}$ pneumoperitoneum $\cdot$ Metastasis $\cdot$ Plasmin activator system $\cdot$ Tumour cell lines

\section{Introduction}

Although there has been a steady increase in the number of laparoscopic colorectal resections of malignant disease since the mid-1990s, minimally invasive procedures were more commonly performed for benign conditions. In this context, the literature refers to the increased proliferation of tumour cells in vitro under $\mathrm{CO}_{2}$ pneumoperitoneum conditions [1] as well as enhanced growth of liver metastases compared to isobaric (gasless) laparoscopy in vivo [2]. Therefore, the question has to be addressed as to whether $\mathrm{CO}_{2}$ pneumoperitoneum may be directly or indirectly related to the enhanced invasion and 
metastatic capabilities of colon cancer cells and to what extent the fibrinolytic system is involved in this process.

During surgery, the intraperitoneal fibrinolytic activity of the plasminogen activator system plays a pivotal role in the maintenance of intraperitoneal fibrinolysis and in the formation of postoperative adhesions. Moreover, the urokinase plasminogen activator (UPA) system is intimately implicated in tumour cell interaction with the extracellular matrix (ECM) and mesothelial cells, both being essential to tumour progression. The uPA system is based on the serine protease plasmin, their activators tissue-type plasminogen activator (tPA) and urokinase-type plasminogen activator (uPA), as well as the plasminogen activator inhibitors PAI-1 and PAI-2 [3]. tPA and uPA effect proteolysis by converting plasminogen to plasmin.

Abdominal insufflation with $\mathrm{CO}_{2}$ causes severe trauma leading to disintegration of the peritoneal mesothelium, which is covered by monolayer mesothelial cells. Electron microscopic investigations revealed morphological changes of the peritoneum under laparoscopic conditions such as high infiltration of granulocytes [4]. Furthermore, changes in pressure, $\mathrm{pH}$ shifts, or dehydration effects may also result in functional impairment. The literature reports only few experimental data on the evaluation of intraperitoneal fibrinolytic activity under laparoscopic conditions. The findings of these studies are controversial [5-8] and focus on the peritoneum with regard to peritoneal healing and the development of clinically relevant postoperative adhesions. However, the effect of pneumoperitoneum on the uPA system has severe consequences for tumour cell progression. Plasmin displays an extended substrate spectrum and degrades fibrin as well as a large number of ECM proteins such as fibronectin or vitronectin. In addition, plasmin activates several metalloproteinases and these in turn degrade ECM, a crucial requirement for activating the metastatic cascade. Proteolysis, effective tumour cell invasion, and metastatic dispersal depend on the balance of the uPA system. In this context, it was recently demonstrated that expression levels of uPA and PAI-1 correlate with the prognosis of bronchial [9], ovarian [10], endometrial cancer [11], breast [12], gastric [13-15], and colon carcinomas [16-24]. $\mathrm{CO}_{2}$ insufflation influences essential cell functions of colon carcinoma cells such as intra- and extracellular $\mathrm{pH}$ values, intracellular calcium levels, and the oxygen partial pressure in the surrounding tissue. Wildbrett et al. [25, 26] demonstrated an evident intra- and extracellular increase in the $\mathrm{pH}$ value from 7.4 to 6.2 due to $\mathrm{CO}_{2}$ application leading to acidification. Small numbers of emerging protons can be buffered, whereas higher concentrations lower intra- and extracellular $\mathrm{pH}$ values. The decrease in intracellular $\mathrm{pH}$ values leads to a series of physiological changes relating to the respiratory chain [27], mitotic activity [28], as well as the secretion of cytokines and inflammation mediators [29]. Additionally, the increased intracellular proton concentration influences the calcium influx into the cell [30]. Even submicromolar increments cause maximum stimulation of calciumdependent signal transduction pathways [31]. Elevated intracellular calcium levels increase gene transcription [32], stimulation of mitosis [33-35], as well as cell migration, enhance transcellular ion transport, neurotransmitter release, acid secretion, and several other cell functions [36].

Previous investigations demonstrated that mechanical deformation of the human colon carcinoma cell line HCT116 causes an increased expression of PAI-1 [37]. Such a deformation of tumour cells following insufflation with $\mathrm{CO}_{2}$ and the subsequent increase in intraabdominal pressure during laparoscopy might be conceivable. Nevertheless, there are no studies on the effect of pneumoperitoneum on the expression of PAI-1 or UPA in tumour cells so far.

The aim of the present study was to evaluate the effect of $\mathrm{CO}_{2}$ pressure and $\mathrm{pH}$ shifts on the expression of uPA, tPA and PAI in colon cancer cells and mesothelial cells.

\section{Material and methods}

\section{Materials}

Unless specified otherwise, all chemicals and reagents were supplied by Sigma-Aldrich (Deisenhofen, Germany). Petri dishes and culture flasks were obtained from Sarstedt (Nuremberg, Germany). Antibiotics were supplied by PAA (Linz, Austria), and PBS (10×), HBSS $(10 \times)$ and trypsin by Invitrogen (Karlsruhe, Germany).

\section{Tumour cell lines}

Human colon carcinoma cell lines WiDr, HCT116 and SW48 (ATCC, Manassas, USA) were routinely cultured on gelatine-coated $(0.2 \%) 25-\mathrm{cm}^{2}$ culture flasks in RPMI supplemented with $10 \%$ FCS, $1 \%$ penicillin/streptomycin at $37^{\circ} \mathrm{C}$ and $5 \% \mathrm{CO}_{2}$ in a humidified incubator. Cells were trypsinized when obtaining $75 \%$ confluence and distributed to 18 Petri dishes (Ø $3.5 \mathrm{~cm}$ ). Experiments were performed in the pneumoperitoneum chamber when $75 \%$ confluency was once more achieved. All colon carcinoma cell lines were derived from primary colon tumours.

\section{Mesothelial cells}

Experiments were approved by the local ethics committee. Human mesothelial cells were isolated from omental adipose tissue according to the protocol of Ivarsson et al. [38] with minor modifications. A $5 \times 5-\mathrm{cm}^{2}$ (approx. $10 \mathrm{~g}$ ) tissue biopsy was washed in $50 \mathrm{ml}$ HBSS, following incubation in HBSS supplemented with $0.05 \%$ trypsin- 
EDTA. Tissue was slightly shaken for $10 \mathrm{~min}$ in $37^{\circ} \mathrm{C}$ and flushed immediately with RPMI supplemented with $20 \%$ FCS to neutralise enzyme activity and to aid in detachment. Cell suspensions were centrifuged for $10 \mathrm{~min}$ at $260 \times \mathrm{g}$ and cultivated in M199 (Gibco, Eggenstein, Germany) $+20 \%$ $\mathrm{FCS}+1 \%$ penicillin/streptomycin at $37^{\circ} \mathrm{C}$ and $5 \% \mathrm{CO}_{2}$ in a humidified incubator. The cells were seeded on gelatinecoated $(0.2 \%) 25-\mathrm{cm}^{2}$ culture flasks. One week later, cells were trypsinized and disseminated in 18 Petri dishes $(\varnothing$ $3.5 \mathrm{~cm}$ ). Experiments were performed following achievement of $75 \%$ confluent cell growth. For immunohistological characterisation, the primary monoclonal antibodies (DAKO, Glostrup) CK7 (clone OV-TL 12/30), CK8 LMV (clone 35ßH11), CK18 (clone DC10) and CK19 (clone RCK108) were used in a 1:100 dilution [39]. Data of mesothelial cell experiments were gathered from four different patients.

\section{In vitro pneumoperitoneum/experimental design}

Tumour cells and similarly mesothelial cells were incubated under three different conditions.

Experimental set $1\left(\mathrm{pH} 6.1+\mathrm{CO}_{2}\right)$ was performed in Petri dishes placed inside a Perspex chamber and incubated at a $\mathrm{CO}_{2}$ pressure of $10 \mathrm{mmHg}$ and a continuous gas flow of $2.5 \mathrm{l} / \mathrm{min}$. The settings of $\mathrm{CO}_{2}$ pneumoperitoneum were mimicked in vitro by an airtight Perspex chamber $(26 \times 26 \times$ $7 \mathrm{~cm}$ ) with one influx for the application of humidified $\mathrm{CO}_{2}$ and two ports to measure gas pressure and saturation, respectively. The pneumoperitoneum chamber was located in an incubator set at $37^{\circ} \mathrm{C}$. Prior to incubation in the chamber, medium was equilibrated for $1 \mathrm{~h}$ to $\mathrm{CO}_{2}$ and $\mathrm{pH}$ was adjusted to 6.1 . After $0.5,1,2$, and $5 \mathrm{~h}$ of incubation in a $99.5 \% \mathrm{CO}_{2}$ atmosphere, samples were harvested.

Experimental set $2(\mathrm{pH}$ 6.1) was performed in a standard cell incubator $\left(5 \% \mathrm{CO}_{2}\right.$ atmosphere) and again $\mathrm{pH}$ was adjusted to 6.1. Under these conditions, the cells were harvested again after $0.5,1,2$, and $5 \mathrm{~h}$ of incubation.
Set 3 (pH 7.4) served as control with cells incubated in a standard cell incubator and physiological $\mathrm{pH}$ of 7.4.

\section{$R N A$ extraction and real-time reverse transcription polymerase chain reaction analysis}

Total RNA was isolated by RNeasy Mini Kit (Qiagen, Hilden, Germany) according to the manufacturer's instructions and stored at $-80^{\circ} \mathrm{C}$.

Concentration and integrity of the total RNA were analysed on a RNA Nano LabChip ${ }^{\circledR}$ Kit (Agilent Technologies, Waldbronn, Germany). Reverse transcription polymerase chain reactions (RT-PCRs) were performed with one-step RT-PCR Kit (Qiagen, Hilden, Germany). Gene expression was quantified using an iCycler iQ real-time detection system (BioRad, Munich, Germany). Amplification was performed using the following intron-spanning primers: PAI-1 forward primer, 5'-CTG ACT TCA CGA GTC TTT CAG ACC-3'; PAI-1 reverse primer, 5'-CCC ATG AAA AGG ACT GTT CCT GTG-3'; uPA forward primer 5'-AGA ATT CAC CAC CAT CGA GA-3'; uPA reverse primer, 5'-ATC AGC TTC ACA ACA GTC AT-3'; tPA forward primer, 5'-CAT AAG GAA TTC GAT GAT GAC ACT TAC GAC-3' and tPA reverse primer, 5'-GAC TGT TCT GTT AAG TAA ATG TTG TGA TGT-3'.

For quantification, the standard curves were established with gene-specific standard cRNA in tenfold dilution series of 0.01 to 1,000 attomol instead of total RNA. The standard curves were generated individually for all genes investigated, and data were calculated by iCycler iQ real-time detection system software (BioRad).

\section{Statistical analysis}

The expression of PAI, uPA and tPA was analysed in an ANOVA model using the statistical software package SAS (Proc Mixed). In the analysis of tumour cell lines, all lines

Table 1 Variance analysis of PAI-1 expression (colon carcinoma cell lines HCT116, SW 48 and WiDr)

\begin{tabular}{|c|c|c|c|c|c|}
\hline & Effect & $p$ value (global) & Paired comparison ${ }^{\mathrm{a}}$ & Ratio $^{b}$ & $p$ values \\
\hline \multirow[t]{4}{*}{ pH 6.1 vs. ctrl. (P vs. C) } & \multirow[t]{4}{*}{ Time ( 0 Ctrl. $), 0,5,1,2$ and $5 \mathrm{~h}$ incubation } & \multirow[t]{4}{*}{$0.0005^{\mathrm{c}}$} & $\mathrm{P} 0.5$ vs. $\mathrm{C} 0$ & 0.51 & 0.2791 \\
\hline & & & P1 vs. C0 & 4.37 & 0.0299 \\
\hline & & & $\mathrm{P} 2$ vs. $\mathrm{C} 0$ & 12.15 & $0.0013^{\mathrm{c}}$ \\
\hline & & & P5 vs. C0 & 10.84 & $0.0018^{\mathrm{c}}$ \\
\hline \multirow[t]{4}{*}{ pH $6.1+\mathrm{CO}_{2}$ vs. ctrl. (P vs. $\left.\mathrm{C}\right)$} & \multirow[t]{4}{*}{ Time ( 0 Ctrl. $), 0,5,1,2$ and $5 \mathrm{~h}$ incubation } & \multirow[t]{4}{*}{$0.0001^{\mathrm{c}}$} & G0.5 vs. $\mathrm{C} 0$ & 0.84 & 0.5733 \\
\hline & & & G1 vs. C0 & 0.71 & 0.2725 \\
\hline & & & $\mathrm{G} 2$ vs. $\mathrm{C} 0$ & 1.18 & 0.5843 \\
\hline & & & G5 vs. C0 & 5.17 & $0.0001^{\mathrm{c}}$ \\
\hline
\end{tabular}

\footnotetext{
${ }^{a}$ Different time points (P) 0.5, 1, 2 and 5 h were compared with the control (C, time 0)

${ }^{\mathrm{b}}$ The ratio of gene expression of the particular paired comparison

${ }^{\mathrm{c}}$ Significant $p$ values after Bonferroni correction for pairwise comparisons (level $\alpha=0.0125$ )
} 
HCT116, SW48, and WiDr were included simultaneously in one analysis. In a second analysis, the mesothelial cells of four patients were investigated together. Two models were investigated for both data sets: (1) experimental set $1(\mathrm{pH}$ $6.1+\mathrm{CO}_{2}$ ) versus control set ( $\left.\mathrm{pH} 7.4\right)$ and (2) experimental set 2 (pH 6.1) versus control set ( $\mathrm{pH}$ 7.4). The time effect in the ANOVA analysis was modelled with five levels identifying the control with time $0 \mathrm{~h}$ and including four time points for the experimental sets $(0.5,1,2$, and $5 \mathrm{~h})$. Four pairwise comparisons were performed between the control and each time point of the experimental set using a Bonferroni-adjusted significance level of $0.0125(=0.05 / 4)$.

In the analysis of tumour cell lines, the PCR was replicated twice for PAI and uPA. These two replications were considered as a random factor nested under the fixed factor cell line. For tPA, the PCR was not replicated, thus, effects of the cell line and the variability produced by the replication of the PCR could not be separated and the cell line was modelled as a random factor. In the analysis of mesothelial cells, the patient was analogously considered as a random factor. All possible fixed and random interaction terms were included in the analysis. Triplets were measured for each PCR and time point (three readings). The ANOVA models were based on the logarithmic expression values. The expression ratio between two groups averaged over the cell lines or patients was estimated by taking the exponential of the mixed model estimates for the logarithmic differences.

\section{Results}

\section{Mesothelial cells}

Cultured cells appeared in a flat "cobblestone" pattern and grew to a confluence of $75 \%$ of the dish surface within 1 week. Cells cultured on plastic slides were immunoreac- tive using antibodies detecting CK8, CK18, and CK19 which are known to be characteristic for mesothelial cells (data not shown) [39]. The cells did not reveal any staining when using the anti-fibroblast antibody (Dianova100, clone 5B5, MO877, Glostrup, Denmark) [38].

No significant differences were found in the expression of PAI-1, tPA and uPA between experimental set 2 (pH 6.1) and set $1\left(\mathrm{pH} 6.1+\mathrm{CO}_{2}\right)$ compared to the control sets $(\mathrm{pH}$ 7.4; data not shown).

Colon carcinoma cell lines

PAI-1 expression increased markedly in all colon carcinoma cell lines (HT116, SW48 and WiDr) in both experimental sets $2(\mathrm{pH} 6.1)$ and $1\left(\mathrm{pH} 6.1+\mathrm{CO}_{2}\right)$ within $5 \mathrm{~h}$ of incubation compared to the control set ( $\mathrm{pH} 7.4$; Fig. 1). The increase of PAI-1 expression in experimental set $1\left(\mathrm{pH} 6.1+\mathrm{CO}_{2}\right)$ was inhibited noticeably at every point in time compared to experimental set 2 (pH 6.1). Insufflation with $\mathrm{CO}_{2}$ diminished the expression of PAI-1 compared to experimental set 2 (pH 6.1, without $\mathrm{CO}_{2}$ ).

Variance analysis of the pooled colon carcinoma cell lines revealed significant differences $(p<0.0125)$ in PAI-1 expression during an observation period from $2 \mathrm{~h}(p=$ $0.0013)$ to $5 \mathrm{~h}(p=0.0018)$ in experimental set $2(\mathrm{pH} 6.1)$ compared to the control set $(\mathrm{pH}$ 7.4). There was a significant increase in PAI-1 expression after $5 \mathrm{~h}$ incubation in set $1\left(\mathrm{pH} 6.1+\mathrm{CO}_{2}\right)$ compared to the control set ( $\left.\mathrm{pH} 7.4\right)$ as well ( $p=0.0001$; Table 1). Whereas PAI-1 expression in set $1\left(\mathrm{pH} 6.1+\mathrm{CO}_{2}\right)$ did not increase significantly before $5 \mathrm{~h}$, the absence of $\mathrm{CO}_{2}$ resulted in a significant increase as early as $2 \mathrm{~h}$.

Moreover, uPA expression increased in experimental set 2 (pH 6.1) after $5 \mathrm{~h}$ incubation compared to the control set (pH 7.4; Fig. 2). This increase was not observed in set 1. Here, no change in uPA expression was observed compared to the control set.
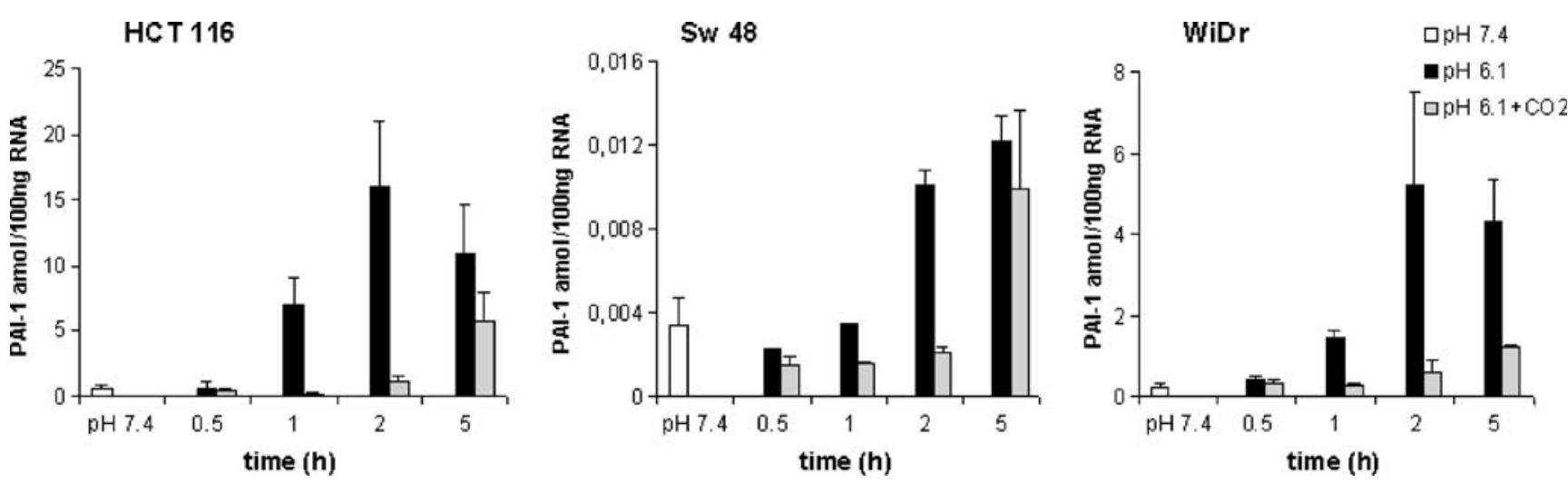

Fig. 1 The effect of $\mathrm{pH} 6.1$ and $\mathrm{pH} 6.1+\mathrm{CO}_{2}$ on RNA expression of PAI-1 using qRT-PCR on colon carcinoma cell lines HCT116, SW48 and WiDr. PH 7.4 served as control. The data were expressed as mean \pm standard error from six readings (two replications of the PCR, each with three readings) 
HCT 116

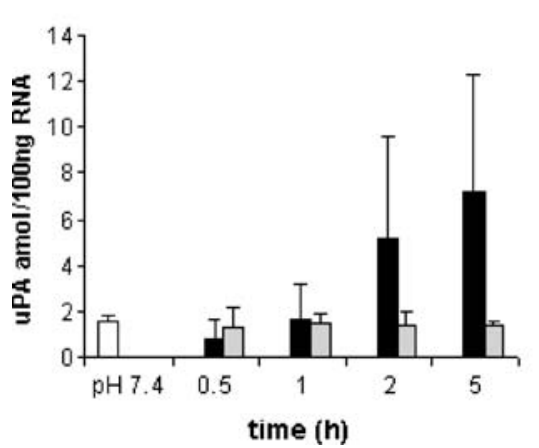

Fig. 2 The effect of $\mathrm{pH} 6.1$ and $\mathrm{pH} 6.1+\mathrm{CO}_{2}$ on RNA expression of uPA using qRT-PCR on colon carcinoma cell lines HCT116, SW48 and WiDr. PH 7.4 served as control. The data were expressed as mean \pm

Variance analysis of pooled cancer cell lines revealed a significant increase in uPA expression in set 2 after $5 \mathrm{~h}(p=$ 0.0039; Table 2). No significant changes were observed in set 1 . Here, insufflation with $\mathrm{CO}_{2}$ inhibited the expression of the plasmin activator uPA.

The tPA expression of the colon carcinoma cell lines in experimental sets 1 and 2 did not exhibit any significant differences when compared to the control set (data not shown).

Furthermore, none of the analyses demonstrated systematically different expression curves for the three tumour cell lines since no interaction between time and cell line was observed.

\section{Discussion}

For the first time, this study investigates the changes in gene expression in the plasmin activator system of colon carcinoma cells as well as mesothelial cells under the conditions of $\mathrm{CO}_{2}$ pneumoperitoneum.

Interestingly, PAI-1 expression is significantly enhanced in colon carcinoma cells when exposed to $\mathrm{pH} 6.1$ and a

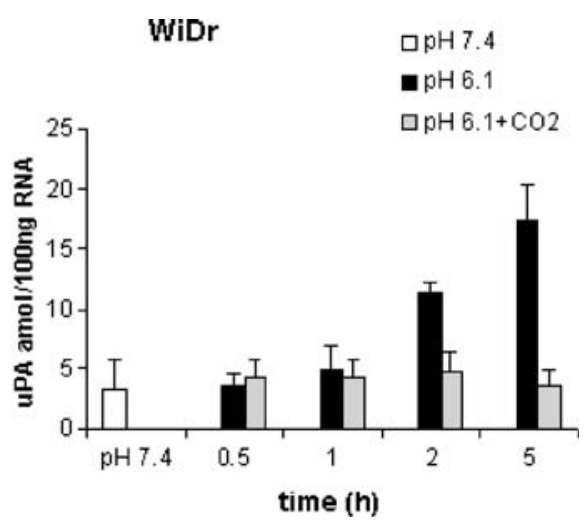

standard error from six readings (two replications of the PCR, each with three readings)

$\mathrm{CO}_{2}$ pressure of $10 \mathrm{mmHg}$ within $5 \mathrm{~h}$ (Fig. 1). Without $\mathrm{CO}_{2}$ insufflation, the increase in PAI-1 expression is always greater. The same changes are observed for uPA expression. Here, the lower $\mathrm{pH}$ enhances uPA expression significantly compared to the control group. However, simultaneous exposure to $\mathrm{CO}_{2}$ has no effect on uPA expression. The acid $\mathrm{pH}$ seems to induce enhanced PAI-1 and uPA expression, but additional $\mathrm{CO}_{2}$ pressure inhibits this effect (Figs. 1 and 2 ). Variance analysis of the tumour cell lines revealed significant differences $(p<0.0125)$ with respect to PAI-1 expression in the analysed groups $(\mathrm{pH} 6.1$ and $\mathrm{pH} 6.1+$ $\mathrm{CO}_{2}$ ) compared to the control group ( $\left.\mathrm{pH} 7.4\right)$ within $2 \mathrm{~h}$ (Table 1). There is also a significant increase in uPA expression (Table 2) in the same tumour cell lines under acid conditions within a time interval of $5 \mathrm{~h}$.

Therefore, it appears likely that the increase in PAI-1 and uPA expression is caused by acid $\mathrm{pH}$ 6.1, a value which matches the intraabdominal conditions during laparoscopic surgery with $\mathrm{CO}_{2}$ insufflation [26]. The inhibition of PAI-1 and uPA expression employing $\mathrm{CO}_{2}$ is confirmed by variance analysis. Additional experiments are warranted to establish the molecular mechanisms of these findings. No

Table 2 Variance analysis of uPA expression (colon carcinoma cell lines HCT116, SW 48 and WiDr)

\begin{tabular}{|c|c|c|c|c|c|}
\hline & Effect & $p$ value (global) & Paired comparison $^{\mathrm{a}}$ & Ratio $^{\mathrm{b}}$ & $p$ values \\
\hline \multirow[t]{4}{*}{ pH 6.1 vs. ctrl. (P vs. C) } & \multirow[t]{4}{*}{ Time (0 Ctrl.), 0,5, 1, 2 and $5 \mathrm{~h}$ incubation } & \multirow[t]{4}{*}{$0.0015^{\mathrm{c}}$} & P0.5 vs. C0 & 0.51 & 0.1772 \\
\hline & & & $\mathrm{P} 1$ vs. $\mathrm{C} 0$ & 1.06 & 0.9092 \\
\hline & & & $\mathrm{P} 2$ vs. $\mathrm{C} 0$ & 3.47 & 0.0213 \\
\hline & & & P5 vs. $\mathrm{C} 0$ & 5.35 & $0.0039^{\mathrm{c}}$ \\
\hline \multirow[t]{4}{*}{ pH $6.1+\mathrm{CO}_{2}$ vs. ctrl. (P vs. $\mathrm{C}$ ) } & \multirow[t]{4}{*}{ Time (0 Ctrl.), $0,5,1,2$ and $5 \mathrm{~h}$ incubation } & \multirow[t]{4}{*}{0.3538} & G0.5 vs. $\mathrm{C} 0$ & 0.87 & 0.4649 \\
\hline & & & $\mathrm{G} 1$ vs. $\mathrm{C} 0$ & 1.27 & 0.2153 \\
\hline & & & $\mathrm{G} 2$ vs. $\mathrm{C} 0$ & 1.14 & 0.4779 \\
\hline & & & G5 vs. $\mathrm{C} 0$ & 1.10 & 0.6129 \\
\hline
\end{tabular}

\footnotetext{
${ }^{\mathrm{a}}$ Different time points (P) 0.5, 1, 2 and $5 \mathrm{~h}$ were compared with the control (C, time 0$)$

${ }^{\mathrm{b}}$ The ratio of gene expression of the particular paired comparison

${ }^{\mathrm{c}}$ significant $p$ values after Bonferroni correction for pairwise comparisons (level $\alpha=0.0125$ )
} 
significant differences were documented for the tPA expression of the tested colon carcinoma cell lines in the experimental sets $1\left(\mathrm{pH} 6.1+\mathrm{CO}_{2}\right)$ and $2(\mathrm{pH} 6.1)$ compared to the control set.

In contrast to tumour cells, the expression of PAI-1, uPA, and IPA in the mesothelial cells revealed no significant differences when compared to the control. These results are confirmed by a prospective randomised study by Neudecker et al. [8] who did not observe any significant differences in UPA, tPA, and PAI-1 expression in peritoneal mesenthelium during laparoscopic colon resection when compared with conventional surgery.

PAI-1 as well as uPA is described to be an important promoter of tumour cell invasion and metastatic spread [40-42]. The antagonist PAI-1 protects the matrix framework, which is required for tumour cell adhesion and migration, against the proteolytic uPA [43, 44], as well as the tumour cells themselves against excessive degradation [45]. Similarly, the main mechanism of PAI-1 is independent of the direct function as an inhibitor of the protease uPA in the plasmin activator system [41, 42]. PAI-1 modulates the interaction between the uPA receptor CD87 coupled to tumour cells and vitronectin $[40,41]$ as well as the connection between vitronectin and the cellular integrin $\alpha_{v} \beta_{3}$ [42]. Therefore, tumour cell adhesion on the cellular matrix is impaired and as a result, tumour cell migration as well as metastatic progression is promoted [46]. Thus, our findings of enhanced expression of PAI-1 in colon cancer cell lines suggest an increase in the invasive potential of colon carcinoma cells under the conditions of prolonged laparoscopic surgery with $\mathrm{CO}_{2}$ insufflation.

Previous studies have emphasised the clear increase in PAI expression in colon carcinoma cells compared to unaffected epithelium [21, 23, 47, 48]. Sier et al. [48] demonstrated a tenfold increase in PAI-1 levels and a twoto threefold enhanced PAI-2 level for colonic adenocarcinoma compared to normal colon epithelium. Several authors confirmed a correlation between the level of PAI1 expression and the prognosis of the 3-year survival rate of patients [17, 18]. Moreover, the PAI-1 expression correlates with the state of differentiation and the infiltration depth of the tumour [16].

Although randomised prospective long-term studies have not revealed any significant survival disadvantage for patients with colon carcinoma after laparoscopic colon carcinoma resection in comparison with conventional surgery, optimisation of the laparoscopic conditions is still desirable from an oncological point of view. Therefore, we hope that this study will encourage the consideration of potential hazards in the process of improving laparoscopic surgery.

Acknowledgement The authors would like to thank Andrew Entwistle for his critical review of this manuscript.
Authors' disclosures Dr. Petra Krause, Dr. Nina Bobisch, Dr. Paul Thelen, Dr. Karola Koehler, Dr. Sarah Koenig, Prof. Heinz Becker and Dr. Ingo Leister have no conflicts of interest or financial ties to disclose.

Open Access This article is distributed under the terms of the Creative Commons Attribution Noncommercial License which permits any noncommercial use, distribution, and reproduction in any medium, provided the original author(s) and source are credited.

\section{References}

1. Jacobi CA, Sabat R, Bohm B, Zieren HU, Volk HD, Müller JM (1997) Pneumoperitoneum with carbon dioxide stimulates growth of malignant colonic cells. Surgery 121:72-78

2. Gutt CN, Kim ZG, Schemmer P, Krähenbühl L, Schmedt CG (2002) Impact of laparoscopic and conventional surgery on Kupffer cells, tumor-associated CD44 expression, and intrahepatic tumor spread. Arch Surg 137(12):1408-1412

3. Li WY, Chong SS, Huang EY, Tuan TL (2003) Plasminogen activator/plasmin system: a major player in wound healing? Wound Repair Regen 11:239-247

4. Volz J, Köster S, Weiss M, Schmidt R, Urbaschek R, Melchert F, Albrecht M (1996) Pathophysiologic features of a pneumoperitoneum at laparoscopy: a swine model. Am J Obstet Gynecol 174:132-140

5. Kopernik G, Avinoach E, Grossman Y, Levy R, Yulzari R, Rogachev B, Douvdevani A (1998) The effect of a high partial pressure of carbon dioxide environment on metabolism and immune functions of human peritoneal cells: relevance to carbon dioxide pneumoperitoneum. Am J Obstet Gynecol 179:1503-1510

6. Bergstrom M, Ivarsson ML, Holmdahl L (2002) Peritoneal response to pneumoperitoneum and laparoscopic surgery. $\mathrm{Br} \mathrm{J}$ Surg 89:1465-1469

7. Nagelschmidt M, Gerbecks D, Minor T (2001) The impact of gas laparoscopy on abdominal plasminogen activator activity. Surg Endosc 15:585-588

8. Neudecker J, Junghans T, Ziemer S, Raue W, Schwenk W (2002) Effect of laparoscopic and conventional colorectal resection on peritoneal fibrinolytic capacity: a prospective randomized clinical trial. Int J Colorectal Dis 17:426-429

9. Pedersen H, Grondahl-Hansen J, Francis D, Osterlind K, Hansen HH, Dano K, Brunner N (1994) Urokinase and plasminogen activator inhibitor type 1 in pulmonary adenocarcinoma. Cancer Res 54:120-123

10. Kuhn W, Schmalfeldt B, Reuning U, Pache L, Berger U, Ulm K, Harbeck N, Spathe K, Dettmar P, Höfler H, Janicke F, Schmitt M, Graeff H (1999) Prognostic significance of urokinase (uPA) and its inhibitor PAI-1 for survival in advanced ovarian carcinoma stage FIGO IIIc. Br J Cancer 79:1746-1751

11. Köhler U, Hiller K, Martin R, Langanke D, Naumann G, Bilek K, Janicke F, Schmitt M (1997) Tumor-associated proteolytic factors uPA and PAI-1 in endometrial carcinoma. Gynecol Oncol 66:268-274

12. Foekens JA, Look MP, Peters HA, van Putten WL, Portengen H, Klijn JG (1995) Urokinase-type plasminogen activator and its inhibitor PAI-1: predictors of poor response to tamoxifen therapy in recurrent breast cancer. J Natl Cancer Inst 87:751756

13. Nekarda H, Schmitt M, Ulm K, Wenninger A, Vogelsang $H$, Becker K, Roder JD, Fink U, Siewert JR (1994) Prognostic impact of urokinase-type plasminogen activator and its inhibitor PAI-1 in completely resected gastric cancer. Cancer Res 54:29002907 
14. Heiss MM, Babic R, Allgayer H, Gruetzner KU, Jauch KW, Loehrs U, Schildberg FW (1995) Tumor-associated proteolysis and prognosis: new functional risk factors in gastric cancer defined by the urokinase-type plasminogen activator system. J Clin Oncol 13:2084-2209

15. Plebani M, Herszenyi L, Cardin R, Roveroni G, Carraro P, Paoli MD, Rugge M, Grigioni WF, Nitti D, Naccarato R (1995) Cysteine and serine proteases in gastric cancer. Cancer 76:367-375

16. Papadopoulou S, Scorilas A, Yotis J, Arnogianaki N, Plataniotis G, Agnanti N, Talieri M (2002) Significance of urokinase-type plasminogen activator and plasminogen activator inhibitor-1 (PAI-1) expression in human colorectal carcinomas. Tumour Biol 23:170-178

17. Loktionov A, Watson MA, Stebbings WS, Speakman CT, Bingham SA (2003) Plasminogen activator inhibitor-1 gene polymorphism and colorectal cancer risk and prognosis. Cancer Lett 189:189-196

18. Berger DH (2002) Plasmin/plasminogen system in colorectal cancer. World J Surg 26:767-771

19. Garcia-Avello A, Galindo-Alvarez J, Martinez-Molina E, CesarPerez J, Navarro JL (2001) Coagulative system activation and fibrinolytic system inhibition activities arise from tumoral draining vein in colon carcinoma. Thromb Res 104:421-425

20. Schwarte-Waldhoff I, Klein S, Blass-Kampmann S, Hintelmann A, Eilert C, Dreschers S, Kalthoff H, Hahn SA, Schmiegel W (1999) DPC4/SMAD4 mediated tumor suppression of colon carcinoma cells is associated with reduced urokinase expression. Oncogene 18:3152-3158

21. Miseljic S, Galandiuk S, Myers SD, Wittliff JL (1995) Expression of urokinase-type plasminogen activator and plasminogen activator inhibitor in colon disease. J Clin Lab Anal 9:413-417

22. Fujii T, Obara T, Tanno S, Ura H, Kohgo Y (1999) Urokinasetype plasminogen activator and plasminogen activator inhibitor-1 as a prognostic factor in human colorectal carcinomas. Hepatogastroenterology 46:2299-2308

23. Buo L, Lyberg T, Jorgensen L, Johansen HT, Aasen AO (1993) Location of plasminogen activator (PA) and PA inhibitor in human colorectal adenocarcinomas. APMIS 101:235-241

24. Herszenyi L, Plebani M, Carraro P, De Paoli M, Roveroni G, Cardin R, Tulassay Z, Naccarato R, Farinati F (1999) The role of cysteine and serine proteases in colorectal carcinoma. Cancer 86:1135-1142

25. Wildbrett $P$, Oh A, Naundorf D, Volk T, Jacobi CA (2003) Impact of laparoscopic gases on peritoneal microenvironment and essential parameters of cell function. Surg Endosc 17:78-82

26. Kuntz C, Wunsch A, Bodeker C, Bay F, Rosch R, Windeler J, Herfarth C (2000) Effect of pressure and gas type on intraabdominal, subcutaneous, and blood $\mathrm{pH}$ in laparoscopy. Surg Endosc 14:367-371

27. Simchowitz L (1985) Intracellular $\mathrm{pH}$ modulates the generation of superoxide radicals by human neutrophils. J Clin Invest 76:1079-1089

28. Shrode LD, Tapper H, Grinstein S (1997) Role of intracellular $\mathrm{pH}$ in proliferation, transformation, and apoptosis. J Bioenerg Biomembr 29:393-399

29. Lovisolo G, Distasi C, Antoniotti S, Munaron L (1997) Mitogens and calcium channels. New Physiol Sci 12:279-285

30. Tombaugh GC (1998) Intracellular $\mathrm{pH}$ buffering shapes activitydependent $\mathrm{Ca} 2+$ dynamics in dendrites of CAI interneurons. J Neurophysiol 80:1702-1712
31. Allbritton NL, Meyer T (1993) Localized calcium spikes and propagating calcium waves. Cell Calcium 14:691-697

32. Berridge MJ (1995) Calcium signalling and cell proliferation. Bioassays 17:491-500

33. Clapham DE (1995) Calcium signaling. Cell 80:259-268

34. Hepler PK (1994) The role of calcium in cell division. Cell Calcium 16:322-330

35. Poenie M, Alderton J, Tsien RY, Steinhardt RA (1985) Changes of free calcium levels with stages of the cell division cycle. Nature 315:147-151

36. Tsien RW, Tsien RY (1990) Calcium channels, stores, and oscillations. Annu Rev Cell Biol 6:715-760

37. Johnson FE, Zhou M, Collins BT, Huang JS (2000) Mechanical deformation induces proliferation of human colorectal carcinoma cells. Int J Oncol 16:617-622

38. Ivarsson ML, Holmdahl L, Falk P, Mölne J, Risberg B (1998) Characterization and fibrinolytic properties of mesothelial cells isolated from peritoneal lavage. Scand J Clin Lab Invest 58(3):195-203

39. Bittinger F, Klein CL, Skarke C, Brochhausen C, Walgenbach S, Röhrig O, Köhler H, Kirkpatrick CJ (1996) PECAM-1 expression in human mesothelial cells: an in vitro study. Pathobiology 64 (6):320-327

40. Kanse SM, Kost C, Wilhelm OG, Andreasen PA, Preissner KT (1996) The urokinase receptor is a major vitronectin-binding protein on endothelial cells. Exp Cell Res 224:344-353

41. Deng G, Royle G, Wang S, Crain K, Loskutoff DJ (1996) Structural and functional analysis of the plasminogen activator inhibitor-1 binding motif in the somatomedin B domain of vitronectin. J Biol Chem 271:12716-12723

42. Stefansson S, Lawrence DA (1996) The serpin PAI-1 inhibits cell migration by blocking integrin alpha $\mathrm{V}$ beta 3 binding to vitronectin. Nature 383:441-443

43. Schmitt M, Harbeck N, Thomssen C, Wilhelm O, Magdolen V, Reuning U, Ulm K, Höfler H, Janicke F, Graeff H (1997) Clinical impact of the plasminogen activation system in tumor invasion and metastasis: prognostic relevance and target for therapy. Thromb Haemost 78:285-296

44. Albo D, Berger DH, Vogel J, Tuszynski GP (1999) Thrombospondin1 and transforming growth factor beta- 1 upregulate plasminogen activator inhibitor type 1 in pancreatic cancer. J Gastrointest Surg $3: 411-417$

45. Grondahl-Hansen J, Christensen IJ, Rosenquist C, Brunner N, Mouridsen HT, Dano K, Blichert-Toft M (1993) High levels of urokinase-type plasminogen activator and its inhibitor PAI-1 in cytosolic extracts of breast carcinomas are associated with poor prognosis. Cancer Res 53:2513-2521

46. Liu G, Shuman MA, Cohen RL (1995) Co-expression of urokinase, urokinase receptor and PAI-1 is necessary for optimum invasiveness of cultured lung cancer cells. Int J Cancer 60:501-506

47. Sier CF, Vloedgraven HJ, Griffioen G, Ganesh S, Nagengast FM, Lamers CB, Verspaget HW (1995) Plasminogen activators and inhibitor type 1 in neoplastic colonic tissue from patients with familial adenomatous polyposis. Br J Cancer 71:393-396

48. Sier CF, Verspaget HW, Griffioen G, Verheijen JH, Quax PH, Dooijewaard G, De Bruin PA, Lamers CB (1991) Imbalance of plasminogen activators and their inhibitors in human colorectal neoplasia. Implications of urokinase in colorectal carcinogenesis. Gastroenterology 101:1522-1528 